\title{
Estimating the effect of burrowing shrimp on deep-sea sediment community oxygen consumption
}

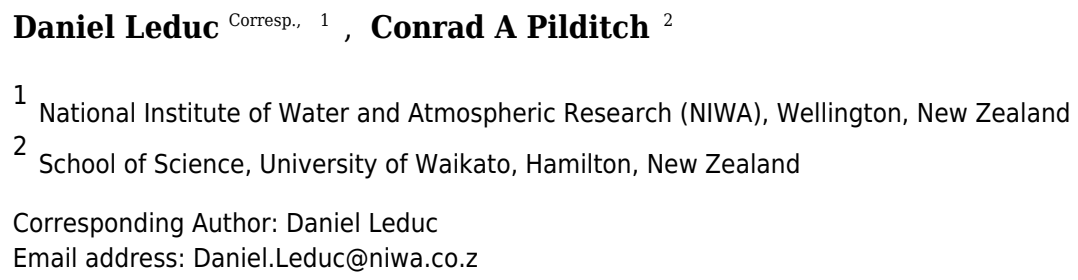

Sediment community oxygen consumption (SCOC) is a proxy for organic matter processing and thus provides a useful proxy of benthic ecosystem function. Oxygen uptake in deepsea sediments is mainly driven by bacteria, and the direct contribution of benthic macroand mega-infauna respiration is thought to be relatively modest. However, the main contribution of infaunal organisms to benthic respiration, particularly large burrowing organisms, is likely to be indirect and mainly driven by processes such as feeding and bioturbation that stimulate bacterial metabolism and promote the chemical oxidation of reduced solutes. Here, we estimate the direct and indirect contributions of burrowing shrimp (Eucalastacus cf. torbeni ) to sediment community oxygen consumption based on incubations of sediment cores from $490 \mathrm{~m}$ depth on the continental slope of New Zealand. Results indicate that the presence of one shrimp in the sediment is responsible for an oxygen uptake rate of about $40 \mathrm{~m} \mathrm{~mol} \mathrm{~d}^{-1}$, only $1 \%$ of which is estimated to be due to shrimp respiration. We estimate that the presence of ten burrowing shrimp $\mathrm{m}^{-2}$ of seabed would lead to an oxygen uptake comparable to current estimates of macro-infaunal community respiration on Chatham Rise based on allometric equations, and would increase total sediment community oxygen uptake by $14 \%$ compared to sediment without shrimp. Our findings suggest that oxygen consumption mediated by burrowing shrimp may be substantial in continental slope ecosystems. 
4 Estimating the effect of burrowing shrimp on deep-sea sediment

\section{community oxygen consumption}

Daniel Leduc ${ }^{a}$, Conrad A. Pilditch ${ }^{b}$

aNational Institute of Water and Atmospheric Research, Private Bag 14-901, Wellington, New Zealand

bSchool of Science, University of Waikato, Private Bag 3105, Hamilton 3240, New Zealand

Abstract

Sediment community oxygen consumption (SCOC) is a proxy for organic matter processing and thus provides a useful proxy of benthic ecosystem function. Oxygen uptake in deep-sea sediments is often assumed to be mainly driven by bacteria, and the direct contribution of benthic macro- and mega-infauna is assumed to be relatively modest. However, the main contribution of infaunal organisms to benthic respiration, particularly large burrowing organisms, is likely to be indirect and mainly driven by processes such as feeding and bioturbation that stimulate bacterial metabolism and promote the chemical oxidation of reduced solutes. Here, we estimate the direct and indirect contributions of burrowing shrimp (Eucalastacus cf. torbeni) to sediment community oxygen consumption based on incubations of sediment cores from $490 \mathrm{~m}$ depth on the continental slope of New Zealand. Results indicate that the presence of one shrimp in the sediment is responsible for an oxygen uptake rate of about $40 \mu \mathrm{mol} \mathrm{d}$ 1 , only $1 \%$ of which is estimated to be due to shrimp respiration. We estimate that the presence of ten burrowing shrimp $\mathrm{m}^{-2}$ of seabed would lead to an oxygen uptake comparable to current estimates of macro-infaunal community respiration on Chatham 
33 Rise based on allometric equations, and would increase total sediment community oxygen uptake by $14 \%$ compared to sediment without shrimp. Our findings suggest that oxygen consumption mediated by burrowing shrimp (and potentially other large burrowing infauna) may be substantial in continental slope ecosystems.

\section{Introduction}

Deep-sea soft sediment communities play an important role in global carbon cycling (Jahnke and Jackson 1992, Archer and Maier-Reimer 1994). The input of particulate organic carbon (POC) from surface waters is the main driver of benthic metabolism in deep-sea sediments (Smith 1987; Pfannkuche 1993), which in turn is influenced by surface (e.g., seasonal and inter-annual variability in climate; Lampitt et al. 2001, Smith et al. 2006), and water column processes (e.g., hydrodynamics, POC recycling and remineralisation by bacteria; Lampitt and Antia 1997, Turner 2002). Processing of organic material and overall metabolism in deep-sea sediments are assumed to be dominated by bacteria and small fauna (e.g., Schwinghamer et al. 1986, Pfannkuche 1993, Beaulieu 2002, Hubas et al. 2006) while the contribution of larger fauna is often assumed to be relatively small (Rowe et al. 2008).

Benthic macro- and megafauna contribute to sediment community oxygen consumption (SCOC) both directly through respiration and indirectly through processes such as feeding, defecation, enzyme release, and bioturbation that stimulate bacterial metabolism and promote the chemical oxidation of reduced solutes (Riemann \& Helmke 2002, Lohrer et al. 2004, Papaspyrou et al. 2010, Bonaglia et al. 2014). Studies in coastal habitats have shown that the main contribution of infauna to SCOC is mediated by these indirect effects and that infaunal respiration itself makes a relatively small contribution (Glud et al. 2000, Glud et al. 2003). Thus, the overall contribution of the infauna to deep-sea ecosystem function is most likely underestimated by allometric equations used to derive the direct contribution of fauna to overall oxygen consumption based only on body size (e.g., Rowe et al. 2008, Leduc et al. 2016). Analyses comparing diffusive oxygen uptake, which is calculated from vertical oxygen gradients in 
65 the sediments and is thought to provide a measure of oxygen consumption by 66 microorganisms, and total oxygen uptake based on changes in oxygen concentrations

67 in overlying water during incubations, suggest that fauna-mediated respiration accounts

68 for an average of about $40-60 \%$ of total benthic oxygen consumption on the upper continental slope (Glud 2008). However, uncertainty remains about the interpretation of diffusive oxygen flux measurements, and the relative contributions of bacteria and other organisms to deep-sea benthic metabolism is still a matter of debate (Rowe \& Deming 2011). Moreover, the contribution to total oxygen uptake of large burrowing macroinfauna living deep in the sediments and in relatively low densities may be underestimated in incubations which are typically based on small areas of sediments (0.01-0.1 $\left.\mathrm{m}^{2}\right)$.

Burrowing shrimp are common in soft sediment environments of temperate and tropical regions, and their burrowing and feeding activities mix surface and subsurface sediment resulting in substantial sediment turnover (Stamhuis et al. 1997, Berkenbusch \& Rowden 1999, Papaspyrou et al. 2004). The presence of burrowing shrimp in coastal systems results in a $70-80 \%$ increase in sediment oxygen demand compared to sediment without shrimp, most of which was due to chemical oxidation reactions and increased microbial respiration (Ziebis et al. 1995, Webb \& Eyre 2004). Burrowing shrimp are likely to impact benthic metabolism in deeper environments such as the upper continental slope where they may also be common (Sakai \& Türkay 1999, Sakai 2005); however no studies have been conducted on their ecology or contribution to ecosystem function in the deep sea. Here, we estimate for the first time the direct and indirect contributions of the burrowing shrimp Eucalastacus cf. torbeni to sediment community oxygen consumption based on incubations of sediment cores from the upper continental slope of New Zealand.

\section{Methods}

The Chatham Rise is a submarine ridge that extends eastwards from the South Island of New Zealand at depths $\sim 250-3000 \mathrm{~m}$. It lies under the Subtropical Front (STF), a region where warm subtropical surface water to the north meets cold, high nutrient-low 
97 chlorophyll subantarctic surface water to the south (Boyd et al., 1999), which is

98 associated with heightened primary productivity (Bradford-Grieve et al., 1997; Murphy et

99 al., 2001). Five undisturbed sediment core samples were obtained at a site at $489 \mathrm{~m}$

100 water depth on the southern flank of the rise (43.8533 $\left.{ }^{\circ} \mathrm{S}, 178.5783^{\circ} \mathrm{E}\right)$ (Figure 1). The

101 samples were collected during a single deployment of an Ocean Instruments MC-800A

102 multicorer (MUC; core internal diameter $=9.52 \mathrm{~cm}$ ) in August 2015 (NIWA voyage

103 TAN1511, station 181). The samples were collected under Special Permit (542) issued

104 by the Ministry for Primary Industries pursuant to section 97(1) of the Fisheries Act

1051996.

106 Estimates of sediment community oxygen consumption (SCOC; in $\mu \mathrm{mol} \mathrm{O}_{2} \mathrm{~m}^{-2} \mathrm{~h}^{-}$

$107{ }^{1}$ ) were obtained using shipboard incubations. Details of the incubation set-ups and

108 measurement protocols are provided in Nodder et al. (2007) and Pilditch et al. (2015).

109 Briefly, the upper 13-15 cm of sediment and the overlying water from undisturbed

110 multicore tubes were carefully extruded into transparent plastic incubation chambers

111 (total volume $=2.0 \mathrm{~L}$ ) with the same internal diameter. Chambers were then sealed and

112 placed in water baths at ambient bottom water temperature $\left(7.3 \pm 0.1^{\circ} \mathrm{C}\right)$ where they

113 were held in the dark for 28-39 h. A magnetically driven impeller fitted to the chamber

114 lids gently circulated water during the incubations. Approximately $6 \mathrm{~h}$ after the chambers

115 were placed in the water bath, $\mathrm{O}_{2}$ concentrations were measured with a pre-calibrated

116 PreSens MICROX I micro-optode. Four to six more $\mathrm{O}_{2}$ measurements were made

117 during the incubation period, which was terminated when the initial concentrations had

118 decreased by $\sim 15 \%$. SCOC was estimated from the decline in $\mathrm{O}_{2}$ concentration with

119 time (linear regression, $r^{2}>0.95$ ).

120 Sediment pigment concentrations (i.e. chlorophyll-a and phaeopigment content)

121 were determined to provide a measure of food availability in the incubation chambers.

122 Immediately after the incubations, the overlying water in the incubation chambers was

123 carefully siphoned out and a sediment sample was obtained using a subcore (internal

124 diameter $=18 \mathrm{~mm}$ ) to a depth of $5 \mathrm{~cm}$. Sediment samples were kept frozen at $-80^{\circ} \mathrm{C}$

125 and pigment concentrations were determined in duplicate using standard techniques

126 (Nodder et al. 2003, 2011). 
Following subcoring for pigment analyses, the remaining sediment was

128

129

130

131

132

133

134

135

136

137

138

139

140

141

142

143

144

145

146

147

148

149

150

151

152

153

154

155

156

157

158 processed for macro-infaunal analyses to help determine any potential differences between cores with and without shrimp. The sediments were sieved onto a $300 \mu \mathrm{m}$ sieve at sea and fixed in $5 \%$ formaldehyde. Samples were sorted using a dissecting microscope and the abundance of major taxa (e.g., polychaetes, amphipods, ophiuroids) was quantified.

Shrimp respiration was estimated based on the allometric equation of Mahaut et al. (1995) relating respiration rate $\left(R, d^{-1}\right)$ to individual dry weight $(W, m g C)$ :

$\mathrm{R}=\mathrm{aW}$

where $a=7.4 \times 10^{-3}$ and $b=-0.24$. Shrimp carbon weight was determined by assuming a wet:dry weight ratio of 4 and a dry:carbon weight ratio of 2.5 (Salonen et al. 1976). The constants $a$ and $b$ were derived by Mahaut et al. (1995), who conducted a linear regression of all published respiration rates of deep-sea organisms. Shrimp respiration $(\mathrm{T})$, expressed as the mass $(\mathrm{mg})$ of carbon dioxide $\left(\mathrm{CO}_{2}\right)$ released $\mathrm{d}^{-1}$, was estimated by multiplying shrimp dry weight $(\mathrm{W}, \mathrm{mg} \mathrm{C})$ by the mass-dependent respiration rate $\left(R, d^{-1}\right)$ :

$$
T=W \times R
$$

Because the equation of Mahaut et al. (1995) is based on measurements conducted at $2-4^{\circ} \mathrm{C}$, and the incubation was conducted at a higher temperature $\left(7.3^{\circ} \mathrm{C}\right)$, estimated shrimp respiration was adjusted assuming a temperature coefficient $\left(Q_{10}\right)$ of 2 . Shrimp respiration was converted to oxygen $\left(\mathrm{O}_{2}\right)$ consumption assuming that one mole of $\mathrm{O}_{2}$ is consumed for each mole of $\mathrm{CO}_{2}$ released (Hargrave 1973).

\section{Results and Discussion}

A total of five undisturbed cores were recovered, which consisted of sandy silt with small amounts of dark glauconite particles typical of the central Chatham Rise (Cullen 1967, Orpin et al. 2008). A small burrow with an opening approximately one centimeter 
159 in diameter was present in the center of one of the cores, which was otherwise similar in 160 appearance to the other cores. At the end of the incubation, which lasted 28 hours for 161 the core containing the burrow opening, the presence of a live shrimp was noted for the

162 first time. The shrimp was later identified as Eucalastacus cf. torbeni, with a length of 12 $163 \mathrm{~mm}$ and wet weight of $3 \mathrm{mg}$. A gently sloping burrow of about eight millimetres in 164 diameter, reaching to a depth of $6 \mathrm{~cm}$ below the sediment surface and with two 165 branches leading to burrow entrances on the edge of the chamber, were visible through 166 the transparent chamber wall. The original burrow opening in the center of the core was 167 still present and was connected to the two new openings by the recently built burrow.

168 The total length of the burrow was estimated as $27 \mathrm{~cm}$, corresponding to a surface area of about $68 \mathrm{~cm}^{2}$. The surface area of an undisturbed (flat) sediment surface in the incubation chamber is $71 \mathrm{~cm}^{2}$, therefore burrow formation by the shrimp led to a doubling of the surface area of the sediment-water interface. The shrimp was intact and moved freely in the burrow; brown particles could be seen in its intestine, suggesting that it had recently been feeding.

Oxygen consumption in the chamber containing the shrimp was about three times greater than the mean oxygen consumption of the chambers without shrimp (332 vs $110-134 \mu \mathrm{mol} \mathrm{m}^{-2} \mathrm{~h}^{-1}$ ) (Figure 2).

Phaeopigment concentration in the shrimp incubation chamber was similar to concentrations in the chambers without shrimp (3.3 vs $2.1-4.4 \mu \mathrm{g} / \mathrm{g}_{\text {sediment }}$ ), whereas chlorophyll-a concentration was two to three times lower in the incubation chamber with shrimp than in chambers without shrimp ( 0.18 vs $\left.0.47-0.62 \mu \mathrm{g} / \mathrm{g}_{\text {sediment }}\right)$. These findings suggest that variation in food availability among the incubation chambers is unlikely to account for the elevated oxygen uptake associated with the presence of burrowing shrimp; on the contrary, it appears that the feeding and burrowing activities of the shrimp may have led to a decrease in chlorophyll-a concentrations in the top five centimeters of sediment relative to incubation chambers without shrimp. Similar decrease in sediment chlorophyll-a concentrations associated with the presence of burrowing shrimp have been observed in intertidal field experiments, presumably as a result of ingestion or burial (Webb \& Eyre 2004), 
The abundance of macro-infauna in the shrimp incubation chamber was slightly

190 higher than in the chambers without shrimp, but the difference was small (152 vs 54-

191151 individuals). Polychaetes were dominant in all chambers and accounted for 46-63\%

192 of total macro-infaunal abundance. The next most abundant taxa were amphipods (7-

$19317 \%$ of total abundance) and nematodes (9-14\%). Although biomass could not be

194 determined in the present study, no obvious difference in size of macro-infaunal

195 organisms were apparent among the cores Thus the elevated oxygen consumption

196 associated with the presence of shrimp is unlikely to be due to differences in the

197 associated macro-infaunal community.

198 Based on the allometric equation of Mahaut et al. (1995) (and assuming a

199 temperature coefficient of 2 to account for temperature difference), respiration by

200 Eucalastacus cf. torbeni $\left(0.59 \mu \mathrm{mol} \mathrm{d}^{-1}\right)$ accounted for about $0.8 \%$ of total respiration in

201 the incubation chamber, and just over $1 \%$ of the average difference in oxygen uptake

202 between incubation chambers with and without shrimp. This result is consistent with

203 previous results suggesting that the majority of the increase in oxygen consumption

204 associated with the presence of burrowing shrimp is due to increased oxidation

205 reactions and/or microbial respiration resulting from the shrimp's burrowing and feeding

206 activities (Koike \& Mukai 1983, Webb \& Eyre 2004). Our estimates suggest that the

207 presence of one Eucalastacus cf. torbeni individual in the sediment is responsible for an

208 oxygen uptake rate of about $1.7 \mu \mathrm{mol} \mathrm{h}-1$ or $40 \mu \mathrm{mol} \mathrm{d}^{-1}$. This value is about 20 times

209 less than the oxygen uptake resulting from the presence of a single burrowing

210 Callianassa japonica or Trypea australiensis individual in subtidal environments (Koike

211 \& Mukai 1983, Webb \& Eyre 2004), which could reflect the larger body size and burrows

212 of the latter species relative to $E$. cf. torbeni and/or the comparatively low metabolic

213 rates of organisms living in cold deep-sea environments. The relatively deep

214 oxygenated layer of deep-sea sediments combined with low organic matter

215 concentrations may also limit the extent to which bioturbation can stimulate oxygen

216 uptake compared to shallow environments.

217 Data on sediment community oxygen consumption, which are typically based on

218 in situ or onboard incubations of small sediment cores that do not include large

219 burrowing fauna, are likely to be underestimating true benthic metabolism rates in deep- 
220 sea habitats (Glud 2008). No estimates are available on the population densities of

221 burrowing shrimp in deep-sea environments; however in shallow environments

222 burrowing shrimp densities range from a few individuals to several hundred individuals

223 per square meter (Berkenbusch \& Rowden 1998, Dumbauld et al. 1996). Images of soft

224 sediment habitats on Chatham Rise often show high densities of burrows and mounds,

225 which are consistent with a high abundance of burrowing shrimp and other bioturbating

226 macro-infauna (Figure 3). However despite the apparently wide distribution of

227 Eucalastacus cf. torbeni on New Zealand's continental margin (S. Mills, pers. com.), no

228 data are available on their densities due to the paucity of sufficiently large and/or

229 quantitative sediment samples. Based on our findings, the presence of ten burrowing

230 shrimp per square meter of seabed, a moderate shrimp density broadly consistent with

231 burrow densities in seabed images in the region, would increase oxygen uptake by 17

$232 \mu \mathrm{mol} \mathrm{m}{ }^{-2} \mathrm{~h}^{-1}$, equivalent to $14 \%$ of current estimates obtained from sediment core

233 incubations from the study site. This density of burrowing shrimp would translate to an

234 oxygen uptake comparable to current estimates of total macro-infaunal community

235 respiration on Chatham Rise based on allometric equations ( 2 to $23 \mu \mathrm{mol} \mathrm{m}^{-2} \mathrm{~h}^{-1}$; Leduc

236 et al. 2016).

237 Besides shrimp, other burrowing macro- and megafauna, such as echiurans,

238 holothurians and ophiuroids, are likely to make a substantial indirect contribution to

239 sediment community respiration. Because these relatively large organisms are

240 vulnerable to physical disturbance from human activities such as bottom trawling (Clark

241 et al. 2016), a decrease in their density and/or diversity would likely result in a loss in

242 ecosystem function. Evaluating the magnitude of this loss, which is likely to be greatest

243 in relatively high productivity upper continental slope habitats where large benthic fauna

244 are most abundant (Leduc et al. 2016), may be aided by the application of functional

245 trait assessment approach (Bremner et al. 2003) and the use of in situ $\mathrm{O}_{2}$ consumption

246 measurement method capable of integrating larger and therefore more representative

247 areas of the seabed, such as in situ benthic chamber incubations (Lichtschlag et al.

248 2015) or the eddy correlation flux method (Berg et al. 2009).

249

250

251 


\section{Acknowledgments}

253

254

255

256

257

258

259

260

261

262

263

264

265

266

267

268

269

270

271

272

273

274

275

276

277

278

279

280

281

We thank the scientific personnel, officers and crew of RV Tangaroa of NIWA voyage TAN1506. We are also grateful to Nathania Brooke (University of Waikato) for her help with the incubations, Jeff Forman (NIWA) for shrimp identification, Sadie Mills (NIWA) for providing Eucalastacus cf. torbeni distribution data, and Ashley Rowden and Matt Pinkerton (NIWA) for their advice and support. We thank Clifton Nunnally and an anonymous reviewer for their constructive criticisms on the manuscript.

\section{References}

Archer D, Maier-Reimer E (1994) Effect of deep-sea sedimentary calcite preservation on atmospheric $\mathrm{CO}_{2}$ concentration. Nature 367, 260-263.

Baguley JG, Montagna PA, Hyde LJ, Rowe GT (2008) Metazoan meiofauna biomass, grazing, and weight-dependent respiration in the Northern Gulf of Mexico deep sea. Deep-Sea Research II 55, 2607-2616.

Beaulieu SE (2002) Accumulation and fate of phytodetritus on the sea floor. Oceanography and Marine Biology 40, 171-232.

Berg P, Glud RN, Hume A, Stahl H, Oguri K, Meyer V, Kitazato H (2009) Eddy correlation measurements of oxygen uptake by deep ocean sediments. Limnology and Oceanography: Methods 7, 576-584.

Berkenbusch K, Rowden AA (1998) Population dynamics of the burrowing ghost shrimp Callianassa filholi (Decapoda: Thalassinidea) on an intertidal sandflat in New Zealand. Ophelia 49, 55-69.

Berkenbusch K, Rowden AA (1999) Factors influencing sediment turnover by the burrowing ghost shrimp Callianassa filholi (Decapoda: Thalassinidea). Journal of Experimental Marine Biology and Ecology 238, 283-292.

Bonaglia S, Nascimento FJA, Bartoli M, Klawonn I, Bruchert V (2014) Meiofauna increases bacterial denitrification in marine sediments. Nature Communications, 5133. 
282 Boyd, P., LaRoche, J., Gall, M., Frew, R. and McKay, R.M.L., 1999. The role of iron,

283

284

285

286

287

288

289

290

291

292

293

294

295

296

297

298

299

300

301

302

303

304

305

306

307

308

309

310 light and silicate in controlling algal biomass in sub-Antarctic water SE of New Zealand. Journal of Geophysical Research 104, 13395-13408.

Bradford-Grieve, J.M., Chang, F.H., Gall, M., Pickmere, S. and Richards, F., 1997. Sizefractioned phytoplankton standing stocks and primary production during austral winter and spring 1993 in the Subtropical Convergence region near New Zealand. New Zealand Journal of Marine and Freshwater Research 31, 201-224.

Bremner J, Rogers SI, Frid CLJ (2003) Assessing functional diversity in marine benthic ecosystems: a comparison of approaches. Marine Ecology Progress Series 254, 11-25.

Clark MR, Althaus F, Schlacher TA, Williams A, Bowden DA, Rowden AA (2016) The impacts of deep-sea fisheries on benthic communities: a review. ICES Journal of Marine Science 73, i51-i69.

Cullen DJ (1967) The age of glauconite from the Chatham Rise, east of New Zealand. New Zealand Journal of Marine and Freshwater research 1, 399-406.

Dumbauld BR, Armstrong DA, Feldman KL (1996) Life-history characteristics of two sympatric thalassinidean shrimp, Neotrypaea californiensis and Upogebia pugettensis with implications for oyster culture. Journal of Crustacean Biology 16, 689-708.

Glud RN, Risgaard-Petersen N, Thamdrup B, Fossing H, Rysgaard S (2000) Benthic carbon mineralization in a high-Arctic sound (Young Sound, NE Greenland). Marine Ecology Progress Series 206, 59-71.

Glud RN, Gundersen JK, Roy H, Barker Jorgensen B (2003) Seasonal dynamics of benthic $\mathrm{O}_{2}$ uptake in a semienclosed bay: Importance of diffusion and fauna activity. Limnology and Oceanography 48, 1265-1276.

Glud RN (2008) Oxygen dynamics of marine sediments. Marine Biology Research 4, 243-289.

Hargrave, B.T. (1973) Coupling carbon flow through some pelagic and benthic communities. Fisheries Research Board of Canada 30: 1317-1326. 
311 Hubas C, Davoult D, Cariou T, Artigas LP (2006) Factors controlling benthic metabolism

312

313

314

315

316

317

318

319

320

321

322

323

324

325

326

327

328

329

330

331

332

333

334

335

336

337

338

339

340 during low tide along a granulometric gradient in an intertidal bay (Roscoff Aber Bay, France). Marine Ecology Progress Series 316, 53-68.

Jahnke RA, Jackson GA (1992) The spatial distribution of sea floor oxygen consumption in the Atlantic and Pacific oceans. In: Deep-sea food chains and the global carbon cycles. Rowe GT, Pariente V Eds. Pp. 295-307, Kluwer Academic

Koike I, Mukai H (1983) Oxygen and inorganic nitrogen contents and fluxes in burrows of shrimps Callianassa japonica and Upogebia major. Marine Ecology Progress Series 12, 185-190.

Lampitt RS, Antia AN (1997) Particle flux in deep seas: regional characteristics and temporal variability. Deep-Sea Research I 44, 1377-1403.

Lampitt RS, Bett BJ, Kirikoulakis K, Popova EE, Ragueneau, Vangriesheim A, Wolff GA (2001) Material supply to the abyssal sea-floor in the Northeast Atlantic. Progress in Oceanography 50, 27-63.

Leduc D, Pilditch CA, Nodder SD (2016) Partitioning the contributions of mega-, macro-, and meiofauna to benthic metabolism on the upper continental slope of New Zealand: Potential links with environmental factors and trawling intensity. Deep-Sea Research I 108, 1-12.

Lichtschlag A, Donis D, Janssen F, Jessen GL, Holtappels M, Wenzhofer F, Mazlumyan S, Sergeeva N, Waldmann C, Boetius A (2015) Effects of fluctuating hypoxia on benthic oxygen consumption in the Black Sea (Crimean shelf). Biogeosciences 12, 5075-5092.

Lohrer AM, Thrush SF, Gibbs MM (2004) Bioturbators enhance ecosystem function through complex biogeochemical interactions. Nature 431, 1092-1095.

Mahaut ML, Sibuet M, Shirayama Y (1995) Weight-dependent respiration rates in deepsea organisms. Deep-Sea Research I 42, 1575-1582.

Murphy, R.J., Pinkerton, M.H., Richardson, K.M. and Bradford-Grieve, J.M., 2001. Phytoplankton distributions around New Zealand derived from SeaWiFS remotesensed ocean colour data. New Zealand Journal of Marine and Freshwater Research 35, 343-362. 
341 Nodder SD, Pilditch CA, Probert PK, Hall JA (2003) Variability in benthic biomass and

342

343

344

345

346

347

348

349

350

351

352

353

354

355

356

357

358

359

360

361

362

363

364

365

366

367

368

369

370 activity beneath the Subtropical Front, Chatham Rise, SW Pacific Ocean. DeepSea Research I 50, 959-985.

Nodder SD, Duineveld GCA, Pilditch CA, Sutton PJ, Probert PK, Lavaleye MSS, Witbaard R, Chang FH, Hall JA, Richardson KM (2007) Focusing of phytodetritus deposition beneath a deep-ocean front, Chatham Rise, New Zealand. Limnology and Oceanography 52, 299-314.

Nodder SD, Maas E, Bowden D, Pilditch CA (2011) Physical, biogeochemical, and microbial characteristics of sediment samples from the Chatham Rise and Challenger Plateau. New Zealand Aquatic and Environment Biodiversity Report 70, 34pp.

Orpin A, Carter L, Goh A, Mackay E, Pallentin A, Verdier AL, Chiswell S, Sutton P (2008) New Zealand's diverse seafloor sediments. NIWA Chart, Miscellaneous Series No. 86.

Papaspyrou S, Thessalou-Legaki M, Kristensen E (2004) Impact of Pestarella tyrrhena on benthic metabolism in sediment microcosms enriched with seagrass and macroalgal detritus. Marine Ecology Progress Series 281, 165-179.

Papaspyrou S, Thessalou-Legaki M, Kristensen E (2010) The influence of infaunal (Nereis diversicolor) abundance on degradation of organic matter in sandy sediments. Journal of Experimental Marine Biology and Ecology 393, 148-157.

Pfannkuche O (1993) Benthic response to the sedimentation of particulate organic matter at the BIOTRANS station, $47^{\circ} \mathrm{N}, 20^{\circ} \mathrm{W}$. Deep-Sea Research II 40, 135149.

Pilditch CA, Leduc D, Nodder SD, Probert PK, Bowden DA (2015) Spatial patterns and environmental drivers of benthic infaunal community structure and ecosystem function on the New Zealand continental margin. New Zealand Journal of Marine and Freshwater Research 49, 224-246.

Riemann F, Helmke E (2002) Symbiotic relations of sediment-agglutinating nematodes and bacteria in detrital habitats: The enzyme-sharing concept. Marine Ecology 23, 93-113. 
371 Rowe GT, Wei C, Nunnally C, Haedrich R, Montagna P, Baguley J, Bernhard J,

372

373

374

375

376

377

378

379

380

381

382

383

384

385

386

387

388

389

390

391

392

393

394

395

396

397

398

399

Wicksten M, Ammons A, Escobar Briones E, Soliman Y, Deming JW (2008)

Comparative biomass structure and estimated carbon flow in food webs in the deep Gulf of Mexico. Deep-Sea Research II 55, 2699-2711.

Rowe GT, Deming JD (2011) An alternative view of the role of heterotrophic microbes in the cycling of organic matter in deep-sea sediments. Marine Biology Research 7, 629-636.

Sakai K, Türkay M (1999) A new subfamily, Bathycalliacinae n. subfam., for Bathycalliax geomarn. gen., n. sp. from the deep water cold seeps off Oregon, USA (Crustacea, Decapoda, Callianassidae). Senckenbergiana Biologica 79, 203-209.

Sakai K (2005) Axiid collections of the Zoological Museum, Copenhagen, with the description of one new genus and six new species (Axiidae, Thalassinidea, Crustacea). Zoologica Scripta 21, 157-180.

Salonen K, Sarvala J, Hakala I, Viljanen ML (1976) The relation of energy and organic carbon in aquatic invertebrates. Limnology and Oceanography 21, 724-730.

Schwinghamer P, Hargrave B, Peer D, Hawkins CM (1986) Partitioning of production and respiration among size groups of organisms in an intertidal benthic community. Marine Ecology Progress Series 31, 131-142.

Smith KL (1987) Food energy supply and demand: a discrepancy between particulate organic carbon flux and sediment community oxygen consumption in the deep ocean. Limnology and Oceanography 32, 201-220.

Smith KL, Baldwin RJ, Ruhl HA, Kahru M, Mitchell BG, Kaufmann RS (2006) Climate effect on food supply to depths greater than 4,000 meters in the northeast Pacific. Limnology and Oceanography 51, 166-176.

Stamhuis EJ, Schreurs CE, Videler JJ (1997) Burrow architecture and turbative activity of the thalassinid shrimp Callianassa subterraneana from the central North Sea. Marine Ecology progress Series 151, 155-163.

Turner JT (2002) Zooplankton fecal pellets, marine snow and sinking phytoplankton blooms. Aquatic Microbial Ecology 27, 57-102. 
400 Webb AP, Eyre BD (2004) Effect of natural populations of burrowing thalassinidean 401 shrimp on sediment irrigation, benthic metabolism, nutrient fluxes and denitrification. 402 Marine Ecology Progress Series 268, 205-220.

403 Ziebis W, Forster S, Huettel M, Jorgensen BB (1996) Complex burrows of the mud 404 shrimp Callianassa truncata and their geochemical impact in the sea bed. Nature $405382,619-622$. 


\section{Figure captions}

408

409 Figure 1. Map of study area east of New Zealand's South Island and the position of 410 sampling site (black filled circle) on Chatham Rise and 250, 500, 1000 and 2000 m 411 water depth contours.

412

413 Figure 2. Mean oxygen consumption in four cores without shrimp and one with a single 414 live Eucalastacus cf. torbeni shrimp specimen. Error bars represent the $95 \%$ confidence 415 interval.

417 Figure 3. Picture of the seabed taken using NIWA's Deep Towed Imaging System 418 (DTIS) on 13 June 2013 (RV Tangaroa voyage TAN1306, station 69) taken 419 approximately 300 m away from study site. Small burrows and mounds can be seen to 420 occur at high densities. The surface area of the image is approximately $1.25 \mathrm{~m}^{2}$ and the 421 scale bar $=20 \mathrm{~cm}$. 


\section{Figure 1}

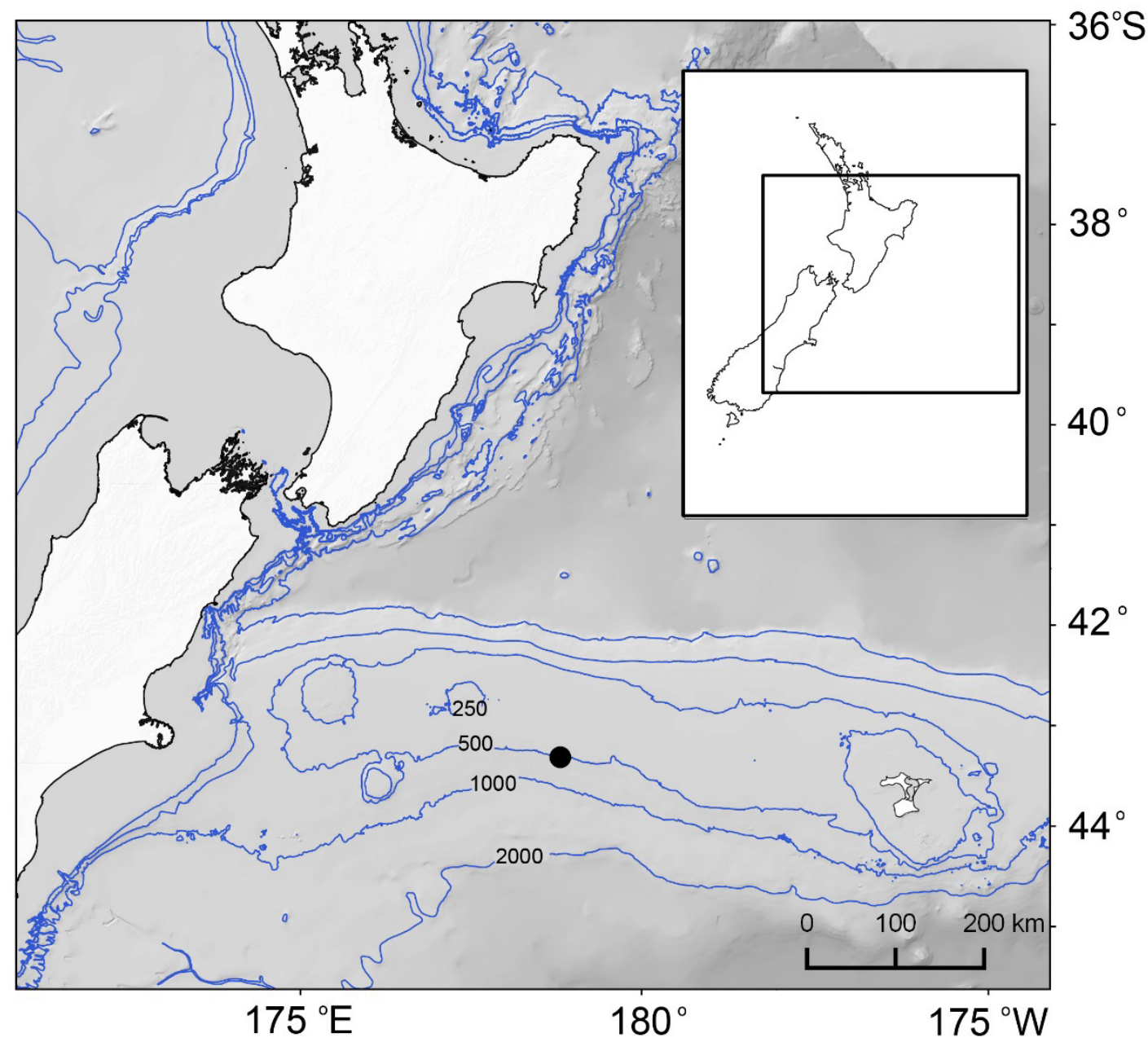

425

426

427

428

429

430

431

432

433

434

435 
436

437

438

439 Figure 2

440

441

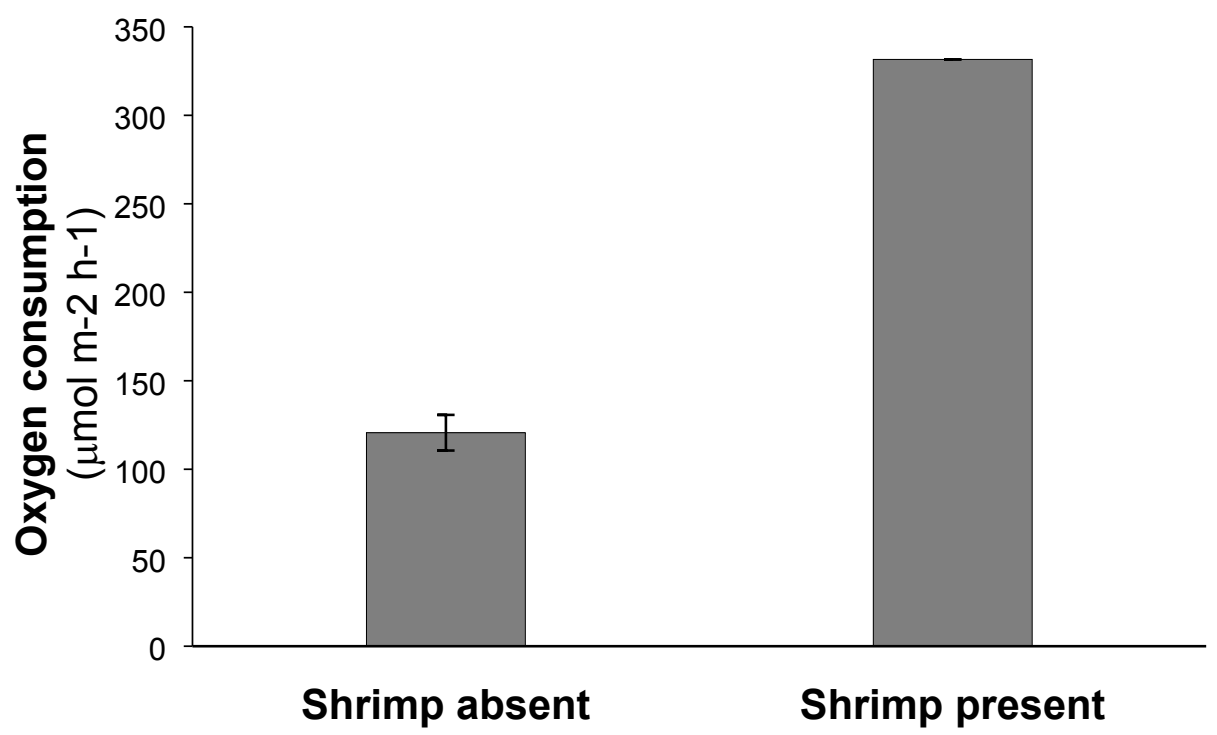

442

443

444 
446 Figure 3

447

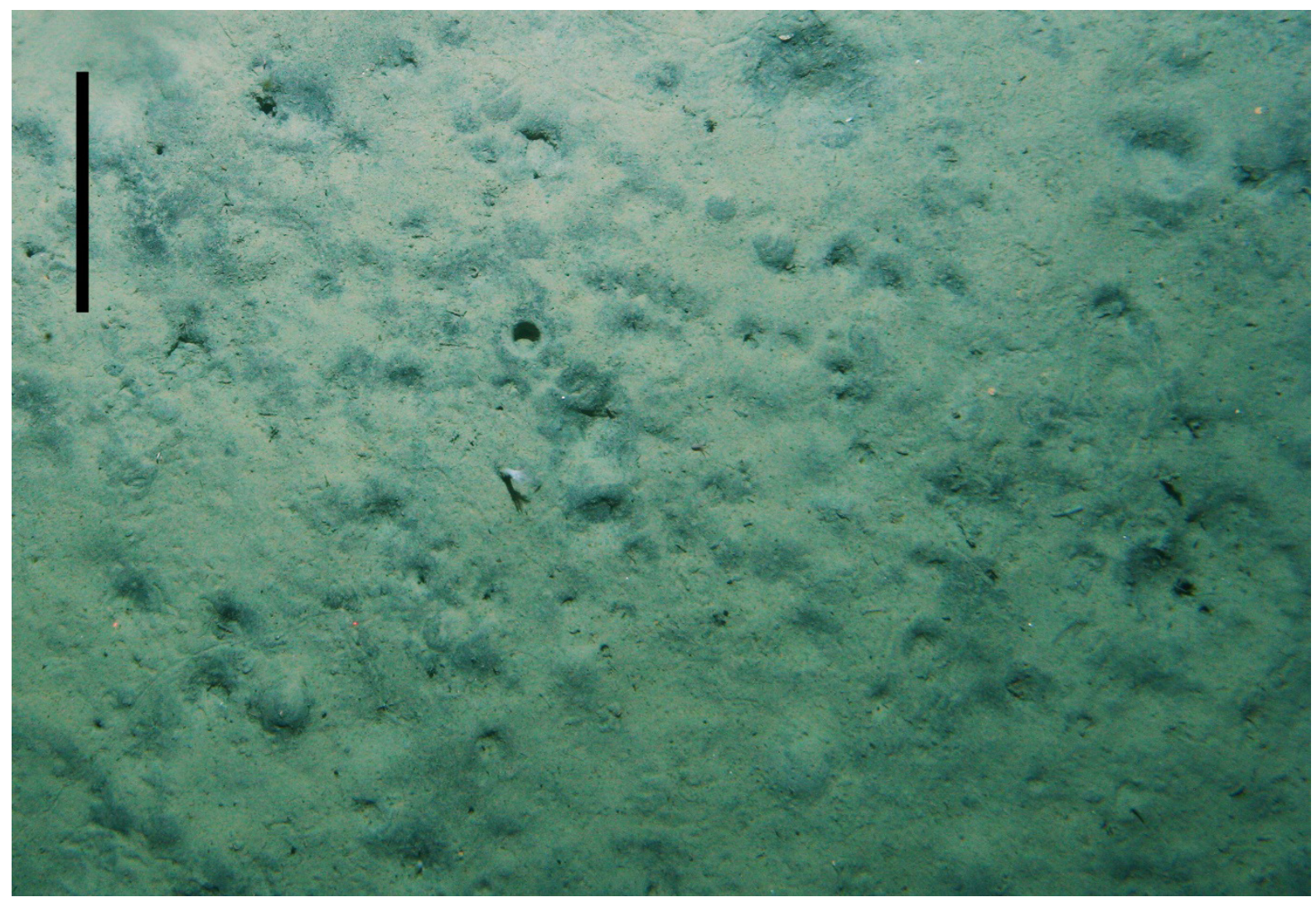

